JKM (Jurnal Kebidanan Malahayati),Vol 7,No.2.April 2021,

ISSN (Print) 2476-8944 ISSN (Online) 2579-762X, Hal 229-233

\title{
MANFAAT KAPSUL DAUN KELOR DALAM MENINGKATKAN KADAR HEMOGLOBIN IBU HAMIL
}

\author{
Rismawati ${ }^{1}$, Vilma Ajijul Jana ${ }^{2}$, Neneng Siti Lathifah ${ }^{3^{*}}$, Sunarsih $^{4}$ \\ 1,3,4Prodi DIV Kebidanan Universitas Malahayati \\ 2 Picoms International University \\ *Korespondensi email nenengmalahayati@gmail.com
}

\section{ABSTRACT: ADVANTAGE OF MORINGA LEAF CAPSULS IN INCREASING HEMOGLOBIN LEVEL TOWARD PREGNANT WOMAN}

Introduction: One of the government policies to increase the nutritional needs of pregnant women is iron supplements. Supplements that contain iron are derived from Fe. The national target is $85 \%$ and the achievement is for those who consume $\mathrm{Fe} \geq 90$ tablets of $30.6 \%$ and $<90$ of $64.5 \%$. This indicates that we have not reached the target.

Purpose: to determine the effect of Moringa leaf capsules on increasing hemoglobin levels in pregnant women at Sumanda Public Health Center.

Methods: This type of quantitative research, the research design used is a quasi-experimental with a two group pretest posttest approach. The population in this study were 33 pregnant women who experienced anemia. A sample of 30 people, 15 people as the intervention group were given treatment by consuming Moringa leaf capsules + Fe and 15 people as the control group who were only given Fe. Sampling of this study was conducted using purposive sampling technique, data analysis using the Independent $T$-test.

Result: The results of univariate analysis showed that the average hemoglobin level in the intervention group before being given Moringa leaf capsules + Fe was $9.907 \mathrm{gr} / \mathrm{dl}$, while in the control group it was 9,800 gr / dl. The average hemoglobin level after being given Moringa + Fe leaf capsules in the intervention group was 11.327 while in the control group was $10.700 \mathrm{gr} / \mathrm{dl}$. 0.90. Bivariate analysis obtained $p$ value $0.000<0.075$, which means $p$ value $<\alpha$.

Conclusion: there is the effect of giving Moringa leaf capsules to pregnant women on hemoglobin levels at Sumanda Public Health Center, Tanggamus Regency in 2019

Suggestion It is hoped that for the community and the Puskesmas the results of this research can be used as evaluation material and a basis for making policies and formulating program plans. For future researchers as a basic source for other researchers to continue research on the comparison of the increase in hemoglobin levels in pregnant women who are given Moringa leaf capsules.

Key words: Moringa leaf capsules, hemoglobin, pregnant women

\section{ABSTRAK}

Latar Belakang: Salah satu kebijakan pemerintah untuk meningkatkan kebutuhan gizi ibu hamil adalah suplemen zat besi. Suplemen yang mengandung zat besi tersebut berasal dari Fe. Adapun target nasional yaitu $85 \%$ dan pencapaiannya yaitu untuk yang mengkosumsi tablet $\mathrm{Fe} \geq 90$ sebesar $30,6 \%$ dan $<90$ sebesar $64,5 \%$. Hal ini menunjukkan bahwa belum mencapai target.

Tujuan: mengetahui ada pengaruh pemberian kapsul daun kelor terhadap peningkatan kadar hemoglobin pada ibu hamil di Puskesmas Sumanda.

Metode:Jenis penelitian kuantitatif, desain penelitian yang di gunakan adalah quasi eksperimen dengan pendekatan two group pretest posttest. Populasi dalam penelitian ini sebanyak 33 ibu hamil dimana yang mengalami anemia. Sampel sebanyak 30 orang, 15 orang sebagai kelompok intervensi diberikan perlakuan dengan mengkonsumsi kapsul daun kelor + Fe dan 15 orang sebagai kelompok control yang hanya diberikan Fe. Pengambilan sample penelitian ini dilakukan dengan menggunakan teknik purposive sampling, analisa data menggunakan uji $T$-test Independent.

Hasil : Hasil analisa univariat didapatkan rata - rata kadar hemoglobin pada kelompok intervensi sebelum diberikan kapsul daun daun kelor + Fe adalah $9,907 \mathrm{gr} / \mathrm{dl}$ sedangkan pada kelompok kontrol $9.800 \mathrm{gr} / \mathrm{dl}$. Rata rata kadar hemoglobin setelah diberikan kapsul daun kelor + Fe pada kelompok intervensi sebesar 11,327 
sedangkan pada kelompok kontrol sebesar $10,700 \mathrm{gr} / \mathrm{dl}$. 0,90. Analisa bivariat didapatkan nilai $\mathrm{p}$ value $0,000<0,075$ yang berarti $p$ value $<a$.

Simpulan: ada pengaruh pemberian kapsul daun kelor Pada Ibu Hamil Terhadap Kadar Hemoglobin di Puskesmas Sumanda Kabupaten Tanggamus Tahun 2019

Saran Bagi masyarakat dna pihak puskesmas hasil penelitian ini diharapkan dapat dijadikan bahan evaluasi dan dasar dalam pengambilan kebijakan serta penyusunan rencana program. Bagi peneliti selanjutnya sebagai sumber dasar bagi peneliti lain untuk melanjutkan penelitian tentang perbandingan kenaikan kadar hemoglobin pada ibu hamil yang diberi kapsul daun kelor.

Kata kunci : Kapsul daun kelor, hemoglobin, ibu hamil.

\section{PENDAHULUAN}

Anemia pada kehamilan merupakan masalah nasional karena mencerminkan nilai kesejahteraan soaial ekonomi masyarakat, dan pengaruhnya sangat besar terhadap kualitas sumber daya manusia. Anemia dalam kehamilan disebut "potential danger to mother an child" (potensial membahayakan ibu dan anak), karena itulah anemia memerlukan perhatian serius dari semua pihak yang terkait dalam pelayanan kesehatan pada lini terdepan (Manuaba,2012)

Prevalensi anemia pada kehamilan di Provinsi Lampung adalah tertinggi dipulau sumatera. Tingginya jumlah anemia di Provinsi Lampung adalah sebesar $69,7 \%$ angka tersebut lebih tinggi dari angka anemia gizi nasional yaitu sebesar $63 \%$. Sedangkan angka kejadian anemia pada ibu hamil di kabupaten Tanggamus pada tahun 2018 sebanyak 48\%. (Dinas Kesehatan Kabupaten Tanggamus, 2018)

Dua kausa tersering anemia selama kehamilan adan nifas adalah defisiensi zat besi dan kehilangan darah akut. Tidak jarang keduanya berkaitan erat larena kehilangan darah dalam jumlah besar disertai hilangnya zat besi hemoglobin serta habisnya simpanan zat besi pada satu kehamilan dapat menjadu kausa penting anemia defisiensi zat besi pada kehamilan selanjutnya. (Leveno,Cunningham, Gant, Alexander, Bloom \& Casey 2009)

Kekurangan zat besi dapat terjadi akibat asupan zat besi tidak memadai dan penyerapan, peningkatan kebutuhan besi selama pertumbuhan, serta kehilangan besi secara berlebih. Anemia dalam kehamilan akan memberikan pengaruh yang kurang baik bagi ibu, baik dalam kehamilan, persalinan, maupun nifas dan masa selanjutnya. Secara umum penyulit yang dapat timbul akibat anemia adalah abortus, kelahiran prematur, persalinan lama akibat inersia uteri, perdarahan pasca melahirkan karena atonia uteri, syok, infeksi saat bersalin maupun pasca melahirkan, dan anemia berat $(<4 \mathrm{gr} \%)$ dapat menyebabkan dekompensasi kordis. Hipoksia akibat anemia dapat menyebabkan syok dan kematian pada persalinan. (Winkjosastro, 2005; Saifudin, 2006; Astuti \& Ertiana, 2018)

Terapi utama pada anemia adalah pemberian suplemen Fe setiap hari $200 \mathrm{mg}$, jika $\mathrm{Hb}$ < 5 -6 gr\% maka diperlukan transfuse darah (Manuaba, 2006; Tri Hartati \& Sunarsih, 2021). Ibu hamil yang mengalami anemia defisiensi besi sangat disarankan untuk melakukan diet makanan yang mengandung besi dan pemenuhan nutrisi adekuat (Astuti \& Ertiana;2008; Hartati \& Sunarsih;2021). Makanan yang baik dikonsumsi sehari - hari diantaranya yaitu bayam, daun katuk, brokoli, hati ayam, dan kacang - kacangan. Selain itu olahan makanan yang banyak mengandung zat besi juga terdapat pada daun kelor (Handayani, 2003: Hartati \& Sunarsih; 2021).

Daun kelor memiliki kandungan gizi yang sangat penting untuk mencegah berbagai macam penyakit. Disamping itu, juha mengandung semua unsur asam amino (essensial) yang sangat penting, yaitu unsur argine, histidine, isoleucine, leusine, lysine, methionine, phenylalinine, threonine, tryptophan dan valine. Selain itu dain kelor mengandung protein, lemak, beta carotene (Vit, $\mathrm{A})$ thiamin (B1), riboflavin (B2), niacin (B3), vitamin C, kalsium, kalori, karbohirdat, tembaga, serat, zat besi, magnesium, dan fosfor, ini merupakan suatu sumber yang luar biasa dari tumbuhan daun kelor (Peter, 2008; Aini Q,2019)

Pada tahun 1999, Fuglie LJ pertama kali mempublikasikan hasil penelitian tantang kandungan nutrisi kelor yang tertuang dalam buku "The Miracle Tree Natural Nutrition for the Tropics". Menurut hasil penelitiannya, daun kelor serbuk mengandung 10 kali vitamin $\mathrm{A}$ yang ada pada wortel, 25 kali zat besi pada bayam, 17 kali kalsium pada susu, 9 kali protein pada yogurt dan 15 kali potassium pada pisang (Krisnadi, 2015; Maryani \& Suryadarma, 2019)

Berdasarkan hasil prasurvey yang telah peneliti lakukan pada bulan Februari Tahun 2019 di 


\section{JKM (Jurnal Kebidanan Malahayati),Vol 7,No.2.April 2021, \\ ISSN (Print) 2476-8944 ISSN (Online) 2579-762X, Hal 229-233}

Puskesmas Sumanda Kabupaten Tanggamus berdasarkan data rekam medik terdapat 69 ibu hamil trimester I-III yang melakukan pemeriksaan kehamilan dimana 33 ibu hamil mengalami anemia, dibandingkan dengan puskesmas Talang Padang dimana dari 43 ibu hamil yang mengalami anemia hanya sebanyak 26 dari jumlah ibu hamil. Upaya preventif dan terapi yang sudah diberikan selama ini adalah dengan pemberian dan sosialisasi konsumsi tablet $\mathrm{Fe}$ serta konsumsi makanan yang mengandung vitamin terutama Fe pada ibu hamil. Saat ini terapi komplementer menjadi aternatif pengobatan dan pencegahan penyakit, terapi tradisional dengan memanfaatkan bahan hebral berupa tanaman yang ada disekitar kita dapat menjadi pilihan yang baik. Oleh sebab itu peneliti mencoba melakukan penelitian dengan memberikan intervensi berupa kapsul daun kelor kepada ibu hamil yang mengalami anemia, karena kelor terbukti memiliki kandungan vitamin yang baik bagi ibu hamil.

\section{METODE PENELITIAN}

Pada penelitian ini penulis membatasi ruang lingkup penelitian sebagai berikut, jenis penelitian ini adalah kuantitatif, dengan rancangan penelitian quasy eksperimen dengan pendekatan Two Group Pretest-Postest Design.Populasi pada penelitian ini adalah seluruh ibu hamil yang mengalami anemia yaitu sebenyak 33 orang, sampel yang di dapatkan yaitu 30 orang yang memenuhi kriteria sampel. Teknik sampling menggunakan purposive sampling.
Pada penelitian ini peneliti membagi responden menjadi 2 kelompok masing- masing 15 orang yang akan diberikan kapsul daun kelor, dan 15 orang tidak diberikan, namun kedua kelompok tetap mengkonsumsi tablet Fe yang sudah diberikan dari puskesmas. Pengambilan data dilakukan dengan pengukuran kadar $\mathrm{Hb}$ baik pada kelompok intervensi maupun pada kelompok kontrol, pengukuran pertama dilakukan sebelum treatmen dimulai (pretest) dan pengukuran kedua dilakukan setelah treatmen selesai (post test). Lalu kedua data HB ibu hamil tersebut di analisa dengan menggunakan analisa univariat dan bivariat. Analisa bivariat menggunakan uji $\mathrm{T}$ - independent.

\section{HASIL DAN PEMBAHASAN \\ Analisis Univariat}

Berdasarkan tabel diatas dapat diketahui bahwa dari 15 responden penelitian, diperoleh hasil nilai mean atau rata-rata kadar hemoglobin sebelum diberikan perlakuan sebesar 9,90, dengan nilai median 9,800, standar deviasi sebesar 0,278, hasil kadar hemoglobin terendah atau minimal yaitu sebesar 9,5 dan hasil kadar hemoglobin tertinggi atau maximal sebesar 10,3 . Nilai mean atau ratarata kadar hemoglobin sesudah diberikan perlakuan sebesar 11.327, dengan nilai median 11.400, standar deviasi sebesar 0.263 , hasil kadar hemoglobin terendah atau minimal yaitu sebesar 10,8 dan hasil kadar hemoglobin tertinggi atau maximal sebesar 11,7 .

Tabel 1.

Kadar Hemoglobin Sebelum Dan Sesudah Konsumsi Kapsul Daun Kelor Dan Tablet Fe

\begin{tabular}{lcccccc}
\hline \multicolumn{1}{c}{ Kadar Hemoglobin } & N & Mean & Median & SD & Min & Max \\
\hline sebelum konsumsi kapsul daun kelor + tablet FE & 15 & 9,90 & 9,800 & 0,278 & 9,5 & 10,3 \\
setelah konsumsi kapsul daun kelor dan tablet FE & 15 & 11.327 & 11.400 & 0.263 & 10,8 & 11,7 \\
\hline
\end{tabular}

Tabel 2.

Kadar Hemoglobin Sebelum Dan Sesudah Konsumsi Tablet Fe

\begin{tabular}{ccccccc}
\hline Kadar Hemoglobin & N & Mean & Median & SD & Min & Max \\
\hline Sebelum konsumsi FE & 15 & 9,800 & 9,700 & 0,2699 & 9,5 & 10,3 \\
Sesudah konsumsi Fe & 15 & 10.700 & 10.500 & 0.2507 & 10,5 & 11,1 \\
\hline
\end{tabular}

Berdasarkan table 2 diatas dapat diketahui bahwa dari 15 responden penelitian, diperoleh hasil nilai mean atau rata-rata kadar hemoglobin sebelum diberikan perlakuan pada sebesar 9,800 , dengan nilai median 9,700, standar deviasi sebesar 0,2699, hasil kadar hemoglobin terendah atau minimal yaitu sebesar 9,5 dan hasil kadar hemoglobin tertinggi atau maximal sebesar 10,3. Rata-rata kadar hemoglobin sesudah diberikan perlakuan sebesar 10.700 , dengan nilai median 10.500 , standar deviasi sebesar 0.2507, hasil kadar hemoglobin terendah atau minimal yaitu sebesar 10,5 dan hasil kadar hemoglobin tertinggi atau maximal sebesar 11,1 . 
Rismawati, Vilma Ajijul Jana,Neneng Siti Lathifah,Sunarsih

Analisis Bivariat

Tabel 3.

Kapsul Daun Kelor dalam Meningkatkan Kadar Hemoglobin Pada Ibu Hamil

\begin{tabular}{lcccc}
\hline \multicolumn{1}{c}{ Kadar Hemoglobin } & N & SD & SE & $P$ value \\
\hline Kelompok Intervensi & 15 & 0.1373 & 0.0355 & \multirow{2}{*}{0.000} \\
Kelompok Kontrol & 15 & 0.0756 & 0.0195 & \\
\hline
\end{tabular}

Berdasarkan tabel 3 diatas dapat diketahui hasil uji t didapat $p$ value $0,000<a(0,05)$ artinya $\mathrm{H}_{0}$ ditolak dan Ha diterima, yang berarti ada Pengaruh Pemberian kapsul daun kelor pada ibu hamil terhadap kadar hemoglobin di puskesmas sumanda tahun 2019.

\section{PEMBAHASAN}

Berdasarkan analisa bivariat dapat diketahui bahwa nilai $p$ value $0,000<a(0,05)$ artinya $H_{0}$ ditolak dan Ha diterima, yang berarti ada Pengaruh Pemberian Kapsul daun kelor Pada lbu Hamil Terhadap Kadar Hemoglobin di Puskesmas Sumanda Tahun 2019

Kebutuhan Fe untuk ibu hamil meningkat untuk pertumbuhan janin. Kebutuhan zat besi trimester 1 kurang lebih $1 \mathrm{mg} / \mathrm{hari}$ (kehilangan basal 0,8 mg/hari) ditambha $30-40 \mathrm{mg}$ untuk kebutuhan janin dan sel darah merah. Kebutuhan zat besi pada ibu trimester II krang lebih $5 \mathrm{mg} /$ hari, (kehilangan basal $0,8 \mathrm{mg} / \mathrm{hari}$ ditambah kebutuhan sel darah merah $300 \mathrm{mg}$ dan conseptus $115 \mathrm{mg}$. Pada trimester 3 kebutuhan zat besi $5 \mathrm{mg} / \mathrm{hari}$ (kehilangan basal $0,8 \mathrm{mg} / \mathrm{hari}$ ) ditambahkan kebutuhan sel darah merah $150 \mathrm{mg}$, conseptus 223 mg. (Merryana Adriani, 2016)

Daun kelor kering mengandung beragam zat/unsur yakni protein $27,1 \mathrm{~g}$, lemak $2,3 \mathrm{~g}$, betakaroten (vitamin A) sebanyak $18,9 \mathrm{mg}$, Thiamin (vitamin B1) sebanyak 2,64 mg, riboflavin (vitamin B2) sebanyak $20,05 \mathrm{mg}$, vitamin C sebanyak 17,83 $\mathrm{mg}$, kalsium sebanyak 2,003 mg, kalori sebanyak 205 kal, karbohidrat sebanyak 38,2 g, serat 19, 2 g dan zat besi sebanyak 28,2 mg (Hendarto, 2019). Menurut Sisanhisari dkk; Secangkir daun kelor cincang mengandung $0,84 \mathrm{mg}$ zat besi, $8 \mathrm{mcg}$ folat dan 1588 IU vitamin A. Studi pada tikut menunjukkan daun kelor menunjukkan efek positif pada paramenter darah sepertu jumlah trombosit, kadar hemogloblin, volume sel darah merah dan lain- lain (Sisanhirasi, dkk, 2020)

Penelitian ini sejalan dengan penelitian yang sudah dilakukan salah satu peneliti sebelumnya tentang konsumsi ekstrak daun kelor dalam meningkatkan kadar hemoglobin pada ibu hamil pada tahun 2018. Dimana berdasarkan hasil analisa univariat dan bivariat diketahui adanya kenaikan rata-rata kadar hemoglobin ibu hamil, dan hasil uji stastistic didapatkan nilai $p$ value $0,000<0,005$ yang artinya ada pengaruh ekstrak daun kelor terhadap peningkatan kadar hemoglobin ibu hamil (Hartati, T., \& Sunarsih, S. (2021)

Anemia kekurangan zat besi pada kehamilan disebabkan kurangnya masukan unsur besi dalam makanan, ganggun reabsorbsi dan lainnya. Kebutuhan zat besi dan vitamin pada ibu hamil jauh lebih tinggi dibandingkan wanita yang tidak hamil. Mengingat dampak dari kekurangan zat besi cukup serius baik bagi ibu dan janin, maka setiap ibu hamil diharuskan mengkonsumsi tablet $\mathrm{Fe}$, terutama ibu hamil dengan anemia. Tablet Fe yang dikonsumsi tidak semuanya dapat diabsorbsi oleh tubuh, oleh sebab itu daun kelor dengan komposisi zat besi dan vitamin yang cukup tinggi mampu membantu penyerapan Fe secara maksimal. Kenaikan kadar hemoglobin pada ibu hamil tentunnya berbedabeda hal tersebut dikarenakan oleh nutrisi ibu hamil yang didapatkan dari makanan yang mereka makan setiap harinya yang dapat membantu pembentukan hemoglobin dan penyerapan konsumsi zat besi seperti protein dan vitamin $\mathrm{C}$.

\section{SIMPULAN}

Berdasarkan hasil penelitian yang telah dilakukan, maka dapat disimpulkan ada Pengaruh Pemberian kapsul daun kelor Pada Ibu Hamil Terhadap Kadar Hemoglobin di Puskesmas Sumanda dengan $p$-value $0,000<0.05$.

\section{SARAN}

Bagi masyarakat dna pihak puskesmas hasil penelitian ini diharapkan dapat dijadikan bahan evaluasi dan dasar dalam pengambilan kebijakan serta penyusunan rencana program. Bagi peneliti selanjutnya sebagai sumber dasar bagi peneliti lain untuk melanjutkan penelitian tentang perbandingan kenaikan kadar hemoglobin pada ibu hamil yang diberi kapsul daun kelor.

\section{DAFTAR PUSTAKA}

Aini, Q. (2019). Analisis Ekstrak Daun Kelor (Moringa Oleifera) pada Pengobatan Diabetes Mellitus. Syiah Kuala University Press. 


\section{JKM (Jurnal Kebidanan Malahayati),Vol 7,No.2.April 2021, \\ ISSN (Print) 2476-8944 ISSN (Online) 2579-762X, Hal 229-233}

Astuti, R. Y., \& Ertiana, D. (2018). Anemia dalam Kehamilan. Pustaka Abadi.

Adriani dan Wirjatmadi. 2012. Pengantar Gizi Masyarakat. Jakarta : Kencana Prenada Media.

Alamaitser, S. 2010. Prinsip Dasar IImu Gizi. Jakarta : PT. Gramedia Pustaka Utama.

Arisman. 2010. Gizi dalam Daur Kehidupan. Jakarta : EGC.

Departemen Gizi dan Kesehatan Masyarakat. Fakultas Kesehatan Masyarakat Universitas Indonesia. 2016.

Diyah Ayu Susilowati, dkk. 2017. Pengaruh Pemberian Buah Kurma Pada Ibu Hamil Dengan Anemia Terhadap Kadar Hemoglobin Di BPM Tri Rahayu Setyaningsih Cangkringan Sleman Yogyakarta

Fadlun \& Achmad Feryanto. 2011. ASuhan Kebidanan Patologi.Jakarta: Salemba Medika.

Hendarto, D. Khasiat Jitu Daun Kelor dan Sirih Merah Tumpas Penyakit. LAKSANA.

Hartati, T., \& Sunarsih, S. (2021). Konsumsi Ekstrak Daun Kelor Dalam Meningkatkan Kadar Hemoglobin Pada Ibu Hamil. Malahayati Nursing Journal, 3(1), 101-107.

Hastono. 2007. Analisa Data Kesehatan. Jakarta : FKM. UI.

Hidayat, Z. Z., Ajiz, E. A., \& Krisnadi, S. R. (2016). Risk factors associated with preterm birth at hasan sadikin general hospital in 2015. Open Journal of Obstetrics and Gynecology, 6(13), 798.

Hidayat. Alimul. 2010.Metode Penelitian Kebidanan Dan Tehnik Analisis Data. Surabaya: Salemba.

Kebidanan, I. (2012). Penyakit Kandungan dan KB. Jakarta: EGC
Lestari Handayani, M. Tanaman Obat untuk Masa Kehamilan \& Pasca Melahirkan. AgroMedia.

Leveno, K. J., Cunningham, F. G., Gant, N. F., Alexander, J. M., Bloom, S. L., \& Casey, B. M. (2009). Obstetri williams: Panduan ringkas. Jakarta: EGC.

Manuaba, I. B. G. (2006). IBG Fajar manuaba. Pengantar Kuliah Bedah. Buku Kedokteran EGC: Jakarta.

Manuaba, IBG. 2012. IImu Kebidanan, Penyakit Kandungan dan KB. Jakarta : EGC.

Merryana Adriani, S. K. M. (2016). Peranan gizi dalam siklus kehidupan. Prenada Media.

Notoatmodjo. 2012. Metodologi Penelitian Kesehatan. Jakarta : PT. Rineka Cipta.

Prawirohardjo, S. 2010. IImu Kebidanan. Jakarta : Yayasan Bina Pustaka.

Saifuddin. 2009. Buku Acuan Nasional Pelayanan Kesehatan Maternal dan Neonatal. Jakarta : Yayasan Bina Pustaka.

Sisanhirasi,dkk. 2020. Pengabdian Masyarakat: Membangun Gerakan Literasi di tenggah Pandemi Covid-19. Sulawesi Selatan: IAIN Parepare Nusantara Press

Sugiyono. 2013. Statistik untuk Kesehatan. Bandung : Alfabeta.

Sugiyono.2014. Metode Penelitian Kuantitatif kualitatif dan $R \& D$. Bandung : ALFABETA.

Sulistyawati, Ari. 2009. Asuhan Kebidanan Pada Masa Kehamilan. Jakarta: Salemba Medika.

Supariasa et al. 2012. Penilaian Status Gizi. Jakarta : EGC.

Tarwoto dan Wasnidar. 2013. Buku Saku Anemia pada Ibu Hamil Konsep dan Penatalaksanaan. Jakarta : Trans Info Media 2007.

Winkjosastro, H. (2005). IImu Kebidanan, Edisi 2. Jakarta: yayasan bina pustaka sarwono prawirohardjo. 